\title{
水田メソコスムによる生物群集に及ぼす 殺虫剂の影響に関する研究
}

\author{
早坂大亮* \\ 近畿大学農学部（前独立行政法人国立環境研究所）
}

（2014年5月 19 日受理）

\section{Study of the impacts of systemic insecticides and their environmental fate in aquatic communities of paddy mesocosms}

\author{
Daisuke HaYASAKA \\ Faculty of Agriculture, Kinki University, 3327-204 Naka-machi, Nara 631-8505, Japan

\begin{abstract}
Keywords: agroecology, biodiversity conservation, community responses, cumulative impacts, ecological risk
\end{abstract} \\ assessment, paddy mesocosms, pesticide residues.
}

\section{は じめに}

水田生態系は水域・陸域ともに生物多様性が高く，この多 様性の高さは農業生産性の向上や生態系サービスの享受に とって重要な要素である ${ }^{1)}$. しかし, 生物多様性の脅威の一 つに, 人工合成化学物質が挙げられ, 社会的関心が急速に高 まっている，農薬は, 安定した農業生産を持続させる上で必 要不可欠であるが, 農耕地という広域の開放系に面的に処理 されるため, 水を媒介して水域に流出・拡散した場合, 農耕 地周辺の生態系に影響を及ぼすことが危惧される。

我が国の農薬登録における要件として, OECDテストガ イドラインに基づく試験 ${ }^{2}$, すなわち魚類 1 種（日本では メダカまたはコイ), 甲殼類のオオミジンコ, および緑藻 (Pseudokirchneriella subcapitata) の「3 種類の標準試験生物 種」に対する個体レベルの室内急性毒性試験の実施が義務

\footnotetext{
* 干 631-8505 奈良県奈良市中町 3327-204

E-mail: hayasaka@nara.kindai.ac.jp; awayotou@hotmail.com (c) 日本農薬学会
}

付けられている。これら試験生物は，（1）生態系の各栄養 段階（高次捕食者，一次消費者，生産者）を代表している， （2）継代飼育・維持が容易である，（3）化学物質に対する 感受性が比較的高い, 等の理由で選定されている ${ }^{3)}$. 農薬の 新規登録または再登録時には，これら生物種による毒性試験 データから得られる急性影響濃度（AEC）と環境中予測濃 度 (PEC) とを比較することで, 必要に応じて農薬登録の保 留や使用規制がかかる。一方, 実験室内で限られた生物種に よる画一的な試験を元にした評価では, 以下のような「リス クの見落とし」が考えられる。第一に複雑な生態系に対する 影響, 第二に地域の固有性, である ${ }^{4)}$. OECDで決められた ガイドラインに準拠しつつも, 各国各地域の特性を加味した 指針を個別に検討していくことも必要である ${ }^{5,6)}$. 化学物質 の真のリスクを的確に予測・評価し, 生物多様性保全につな げるためには, 個体〜個体群〜群集に至る各レベルで観察さ れる生物反応のメカニズムの中から, 化学物質の影響の観点 からの共通性・相似性を解明することが重要であり, そのた めの各種評価手法の確立およびシステムの構築が急務であ $ろ^{4,7,8)}$. しかし, 現状, 生物の生態リスクに関して, 室内毒 
性試験（個体レベル）よりも高次（群集・生態系レベル）の 評価システムは, 種の感受性分布 (Species Sensitivity Distribution: SSD）などの統計学的推定アプローチを除き9,10), 各種農薬の物理化学特性等に柔軟に対応する目的から, 明確 な基準等は設けられていない ${ }^{11)}$.

そこで, 本研究では, この課題に対応すべく, 野外におけ る生態リスク評価の有効な手法の一つと考えられている実 験生態系（メソコスム）試験を用いて ${ }^{12)}$, 水稲用農薬とし て，近年，急速に普及している浸透移行型の箱苗処理剂に着 目し, 農耕地周辺生態系への影響に先立ち, 農薬による水田 における生物多様性への影響の解明を試みた。メソコスムは 農薬に限らず，各種ストレスが生態系に与える影響を評価す る手法の一つとして広く用いられており ${ }^{13,14)}$ ，(1）多種類の 生物種に対する影響を同時並行的に試験可能，（2）無処理区 が設置可能, という点で農薬濃度以外の環境条件を可能な限 り均一化でき, 農薬自体の影響を検出しやすいことから, 室 内毒性試験の検証や生態系の変動メカニズムの解明に重要な 役割を担うと期待されている（農薬管理行政の現状と課題に 関する詳細は，早坂ら ${ }^{8)}$ を参照されたい)，加えて，従来の リスク評価で考慮されてこなかった，農薬の残留性・蓄積 性 ${ }^{15,16)}$ に着目して, メソコスムにおける長期曝露, すなわち 連用による影響も明らかにした。本稿では，筆者がこれまで 実施してきたメソコスム試験の成果について概説する.

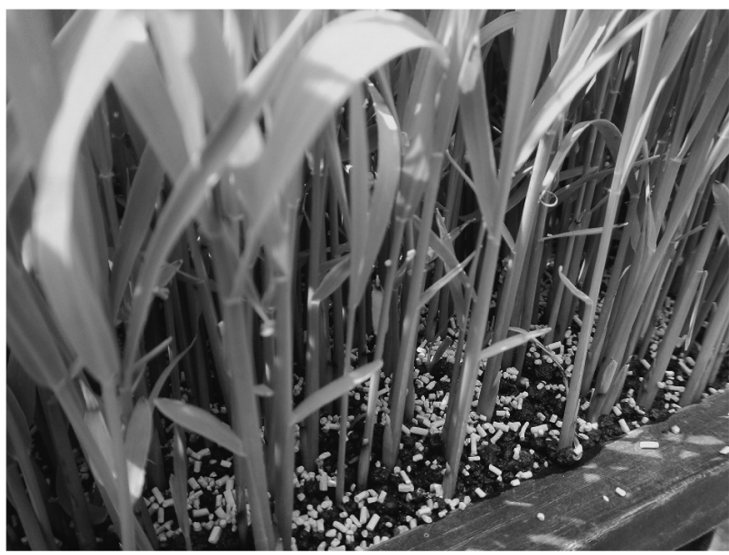

(a)

\section{1. 材料と方法}

\section{1. 対象農薬}

試験対象農薬は, 普及率が高く, かつ物理化学的性状の異 なるイミダクロプリド（商品名：アドマイヤー ${ }^{\circledR} 1$ 粒剂, バ イエルクロップサイエンス，東京）およびフィプロニル（商 品名：プリンス ${ }^{\circledR}$ 粒剂, 日産化学工業, 東京) を有効成分と する2つの箱苗処理剂とした。各農薬の標準使用量の年 1 回 のみの投薬による生物群集への影響について, 流水式の人工 水田（長さ $5.2 \mathrm{~m} \times$ 幅 $1.6 \mathrm{~m} /$ 田）という半自然条件（水田メ ソコスム）で，2010年4月から 2012年9月まで，3年にわた り調査した（なお，本試験は現在も継続中である）。試験は, 茨城県つくば市の国立環境研究所で行った（Fig. 1). イミダ クロプリドは水溶性が高く土畩に吸着しにくい特性を有し, 一方，フィプロニルは，疎水性が高く土㙵に吸着しやすいと されている. なお, 光, 加水分解, 底質, および土埪中の半 減期間に両剂で大きな違いは見られない（Table 1)。標準試験 生物種等に対する安全性は，イミダクロプリドの方が数十〜 数千倍高いと評価されている ${ }^{17,18)}$.

これらの物理化学的性状および環境生物に対する安全性の 差が，水田メソコムス内に生息する生物群集に対してどのよ うな影響を及ぼし，また，どのような回復過程をたどるのか について評価した。

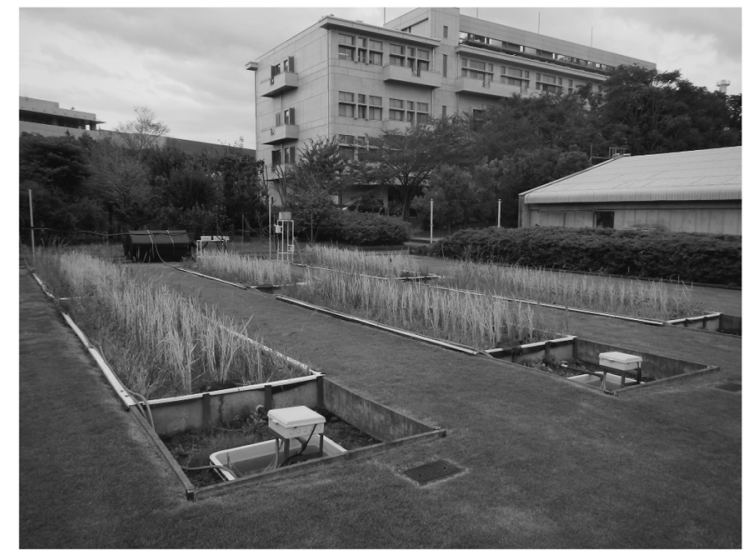

(b)

Fig. 1. Outlines of the paddy mesocosm study. (a) Nursery-box applied systemic insecticides, (b) experimental paddies.

Table 1. Characteristics of imidacloprid and fipronil (Source: Footprint Database http://sitem.herts.ac.uk/aeru/iupac/)

\begin{tabular}{lcccccc}
\hline & & & & \multicolumn{2}{c}{ Half-life $(\mathrm{d})$} \\
\cline { 5 - 7 } Compound & $\begin{array}{c}\text { Water solubility } \\
(\mathrm{mg} / \mathrm{L})\end{array}$ & $\begin{array}{c}\text { Partition coefficient } \\
\left(\log K_{\mathrm{ow}}\right)\end{array}$ & $\begin{array}{c}\text { Photolysis } \\
(\mathrm{pH} 7)\end{array}$ & $\begin{array}{c}\text { Hydrolysis } \\
(\mathrm{pH} 5 \text { to } 7)\end{array}$ & Water-sediment & Soil (range) \\
\hline Imidacloprid & 610 & 0.57 & 0.2 & Stable & $30-129$ & $191(104-228)$ \\
Fipronil & 3.78 & 3.75 & 0.33 & Stable & $54-68$ & $142(5.6-346)$ \\
\hline
\end{tabular}




\section{2. モニタリング方法}

作付期間中（5月上旬から 9月下旬までの 4 カ月）の無処 理区および農薬処理区における, 水中・土袞中の農薬濃度お よび生物データ（動物プランクトン, 底生生物, 水生昆虫類 各種の個体数, および放流したヒメダカの生残・成長）につ いて, $1 \sim 2$ 週間に 1 度の頻度で分析・計測した。

水サンプルについては, 水田メソコスム内の任意の複数の 箇所から，併せて $500 \mathrm{~mL}$ 採水した。土壌サンプルについて も同様に, 任意の複数の箇所から表層 $3 \mathrm{~cm}$ 以内の土㙵を計 $500 \mathrm{~g}$ 採取した. なお, 水・土袞ともに分析までの期間, 光 分解等の影響を排除するため, サンプルボトルにアルミホイ ルをまいて遮蔽し， $-80^{\circ} \mathrm{C}$ のディープフリーザー内で凍結 保存した。

動物プランクトンは, 水田メソコスム内の任意の複数の 地点から計 $1 \mathrm{~L}$ の水を採水し, 直径 $30 \mathrm{~cm}$, メッシュサイズ $250 \mu \mathrm{m}$ の簡易プランクトンネットで濾し, ネット内に残っ た各種の個体数を計測した。底生生物は, 直径 $10 \mathrm{~cm}$ の塩化 ビニル製パイプを水田内の任意の 3 か所に設置し, 表層 $3 \mathrm{~cm}$

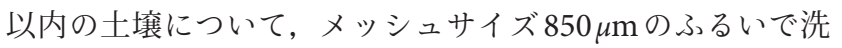
浄して, ろるいに残った個体について計測した. 水生昆虫類 は, 水田内の両端に設置した畔と移植株との間の $20 \mathrm{~cm}$ 程度 の隙間を対象に, 幅 $20 \mathrm{~cm}$ の魚網ですくい取った各種の個体 数を計測した ${ }^{16,19)}$.

\section{3. 濃度分析方法}

水中および土培中のイミダクロプリド残留物の抽出は, 固 相抽出法を用いて行った ${ }^{16,19)}$. 得られた抽出物を精製し, LC-MS/MS（Waters社製Xevo-TQ）にて測定を行い, 濃度 を算出した. フィプロニルについてもイミダクロプリドと 同様の手法で抽出・精製を行い, GC-MS/MS（Varian社製
CP-3800）により濃度を測定した。

以下に, 水田メソコスム試験結果の概要を述べる.

\section{2. イミダクロプリドおよびフィプロニル剤の 水田環境中の動態}

イミダクロプリド剂の水中における最高濃度は 3 年間通じ て移植直後（2時間後）であり, 濃度の差も比較的小さかっ た $(20 \sim 50 \mu \mathrm{g} / \mathrm{L})$. フィプロニル率における最高濃度はいず れの年も, イミダクロプリドの $1 / 10$ 以下の $1 \mu \mathrm{g} / \mathrm{L}$ 程度の微 量濃度であった (Fig. 2). なお, 両剤の水中における濃度半 減期（ $\left.\mathrm{DT}_{50 \_ \text {water }}\right)$ はいずれの年も，1２週間程度であった。 このことから, これら農薬の水中における曝露濃度は, 農薬 の使用年数に関わらずおおよそ一定であることがわかる。こ の理由として, 両剤ともに排水 ${ }^{20)}$, 日射 ${ }^{21)}$ や光分解 ${ }^{22)}$ によ り逈減しやすいことが指摘されている。なお，上記濃度は, 登録保留基準值（イミダクロプリド : $8,500 \mu \mathrm{g} / \mathrm{L}$, フィプロ ニル：19 $\mu \mathrm{g} / \mathrm{L} ）$ の数十〜数千分の一の濃度であるが, 後述 のように, 群集・生態系レベルでは長期の影響をもたらす濃 度である。

一方, 土壌中の残留濃度には, 農薬間, 年度間で大きな違 いが見られた。フィプロニル剤はその土壌吸着性の高さか ら（Table 1)，サンプル日間で濃度に大きなばらつきがみら れた（数〜 $200 \mu \mathrm{g} / \mathrm{kg}$ ).このことは, 本剤が移植株元から溶 出〜拡散しにくい性質を有するため, 濃度分布が空間的に 不均一になることを示唆している。また，3年間通じて試験 終了時点で数 $\mu \mathrm{g} / \mathrm{kg}$ 程度の残留が見られた. イミダクロプリ ド剤の土壌半減期 $\left(\mathrm{DT}_{50 \_s o i l}\right)$ は2 週間〜 1.5 カ月程度であっ たが, 処理 2 年目 (2011年) 以降, 土袞中の濃度が明確に 上昇するとともに, 試験終了時点で $2 \mu \mathrm{g} / \mathrm{kg}$ の濃度が検出さ れた (Fig. 2).この結果は, 本試験の水田メソコスム条件で

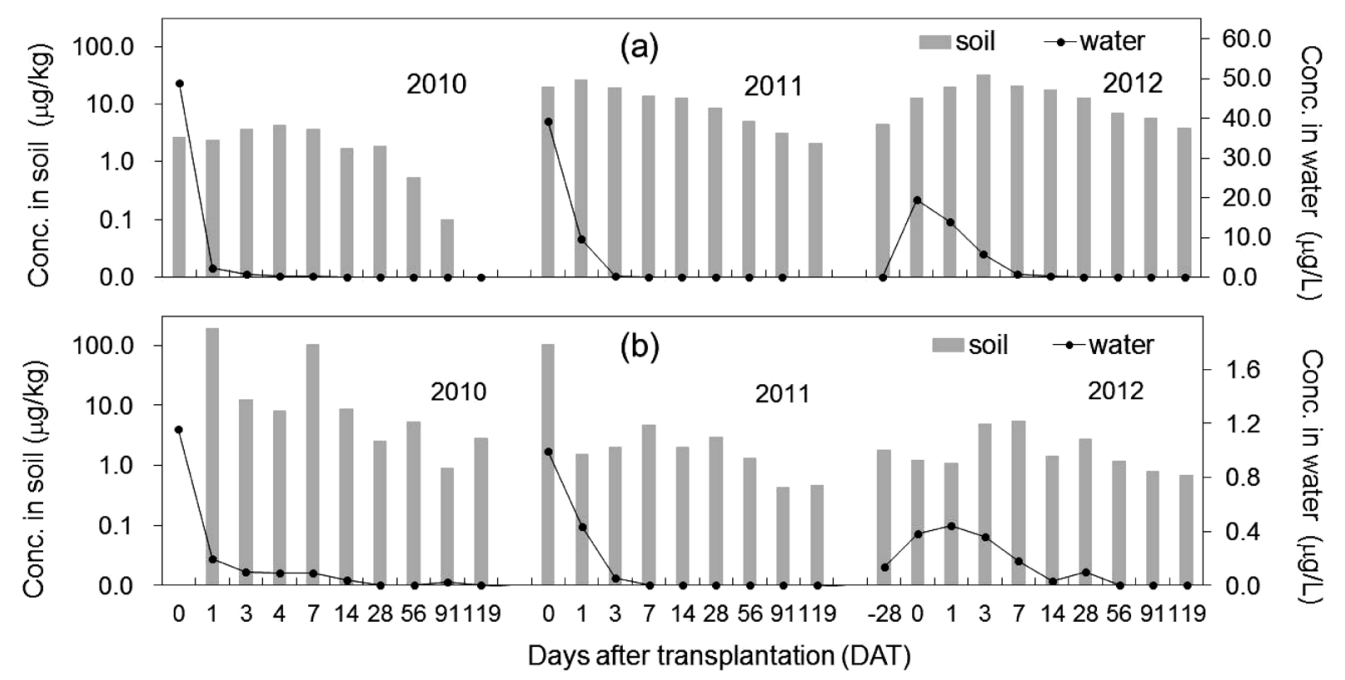

Fig. 2. Dissipation behaviors of (a) imidacloprid and (b) fipronil in water and soil of experimental paddy fields during three years (2010-2012). 
は，前年度の農薬が残留していたことを示すものである.

本研究において, 両剤とも2011年の試験終了時とほぼ同 じ濃度が2012年の試験開始前の土袞から検出された。この ことは, 晚秋から早春季の乾田期間中に日射等により分解・ 消失することなく, 残留したことを示唆するものである. 加 えて, 土壌吸着係数 $\left(K_{\mathrm{oc}}\right)$ の低い, すなわち土壌中の残留 性が低いと想定されていたイミダクロプリドを含め, 連続し て処理すると土壌中での残留が長期化する傾向が見られた. その原因の一つとして, 連用に伴う微生物活性の低下によ り, 環境中での分解速度が遅くなったことが考えられる。一 方, イミダクロプリドの土壤中の分解パターンは光条件に大 きく依存するとともに, 嫌気性土袞条件下で分解速度が速ま ることが知られている. (3) $^{23}$

\section{3. 水田生物多様性に対する農薬の連用の影響}

これまでの農薬の生態リスク研究の多くは, 処理後の比較 的短期間（数週間〜数力月）における生物の挙動で評価して きた ${ }^{24-26)}$. EUのガイダンス文書においても, 水圈生態系へ の影響評価期間を 8 週間と定めている ${ }^{27)}$.

本研究の結果から, 生物群集の構造に対する農薬曝露の 影響は, 処理 2 年目以降に顕著に現れはじめ, かつ, 連用を 続けるほど大きくなる, また，その傾向は主に水生昆虫類の 結果を反映していることが明らかとなった（Fig. 3). 特に, フィプロニル処理区においては, 処理 2 年目以降, 作付期間
中に無処理区と同様の群集構造に回復することはなかった (Fig. 3a).このことは初期曝露の効果が, その後の曝露に対

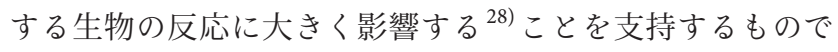
ある. もちろん, 水田土壌中の微生物活性の低下や気象条件 の年変動等による影響の可能性も否定できない. 一方, 曝露 後の群集の回復性は生物群で大きく異なった．動物プランク トンおよびユスリカ科の幼虫やイトミミズ類をはじめとする 底生生物は，3年間通して影響期間は一時的であり，また， 群集変化の程度や変動のパターンも 2 年目以降捛おむね類似 していた (Fig. 3b,c). しかし, ガムシ, ゲンゴロウやミズ ムシ等の水生昆虫類は, 処理 1 年目ではほとんど影響は確認 されなかったが，2年目になって見られるようになり，3年 目では, フィプロニル処理区において, 作付期間中の群集の 回復が見込めないほど顕著な群集影響を引き起こした（Fig. 3d). 同様の傾向は, トンボ類の幼虫群集においても報告さ れており ${ }^{29)}$, フィプロニル処理の影響は 1 年目では明確に検 出できなかったが, 処理 2 年目にはトンボ類幼虫の個体数が 無処理区に対して $77 \%$ も低下する傾向が見られた（Figs. 4, 5).これら農薬に対する生物群間の感受性の違いには, 各 生物種の生息域（ハビタット）が大きく関わると考えられ る ${ }^{16)}$. プランクトンは浮遊性であり, 水中での曝露が主要 な経路となるため, 水溶性が高いイミダクロプリドによる曝 露を受けやすいと推察される. 一方, 底生生物や水生昆虫類 は土壌表層や土中を主要な生息場所とすることから, 土壤吸
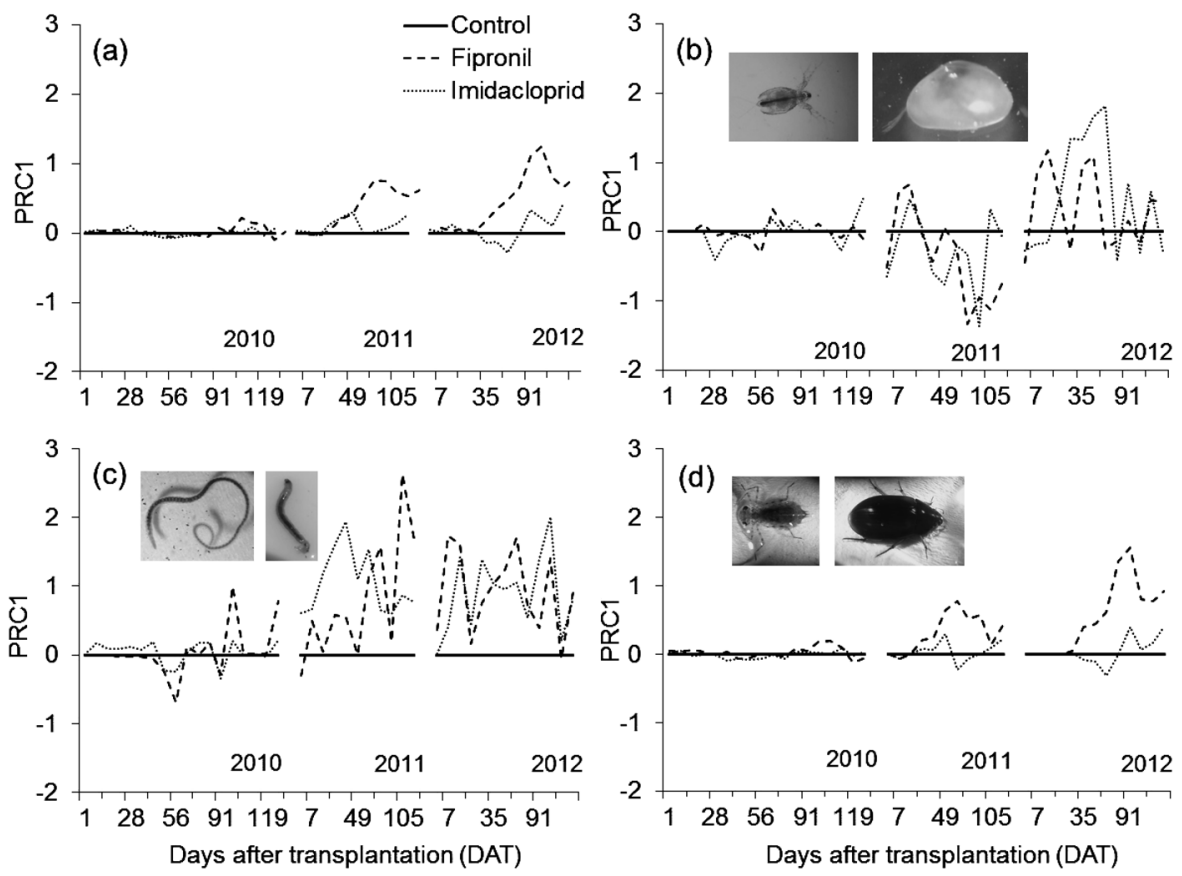

Fig. 3. Principal Response Curve (PRC) indicating the effect of the insecticides imidacloprid and fipronil on paddy communities of the experimental paddy mesocosms during three years (2010-2012). The vertical axis represents the difference in community structure between controls versus insecticide-treated mesocosms, expressesed by the regression coefficient $\left(C_{\mathrm{dt}}\right)$ of the PRC model. (a) All aquatic organisms, (b) zooplankton communities, (c) benthic communities, and (d) aquatic insects. 
(a)

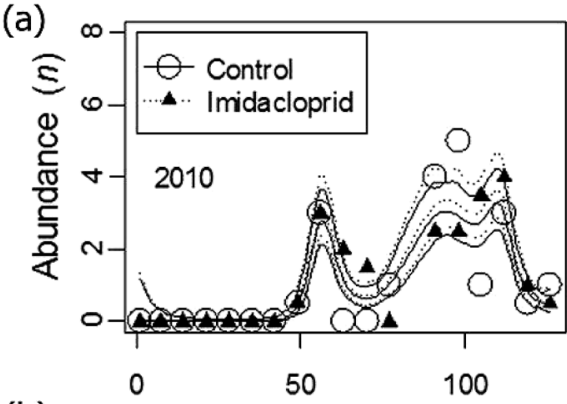

(b)

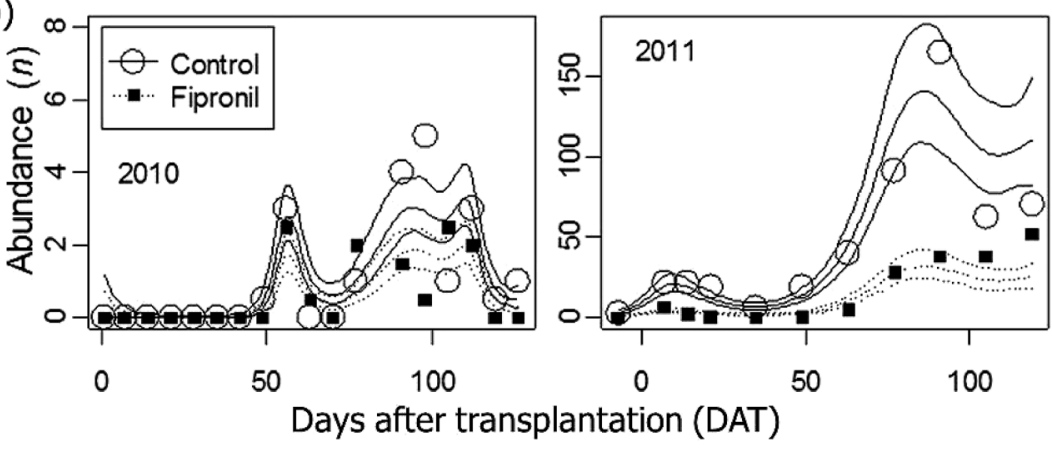

Fig. 4. Observed and predicted abundance of dragonfly nymphs between (a) imidacloprid-treated fields and controls and (b) fipronil-treated fields and controls throughout the entire cultivation period of 2010 and 2011 . The symbols $(\bigcirc$, controls; $\boldsymbol{\Delta}$, imidacloprid; and $\boldsymbol{\square}$, fipronil) indicate the mean observed values of two replicates of each treatment. A set of three lines indicates the predicted mean and quantiles of standard error (SE) estimated by the generalized additive model (GAM). The SE calculated by the GAM was of a logarithmic mean, and we showed mean $\times \exp (\mathrm{SE})$ and mean/exp(SE) as upper and lower quantiles, respectively. Reprinted with permission from ref. 29.

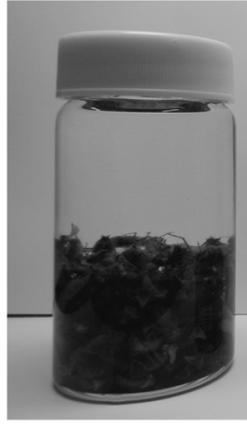

(a)
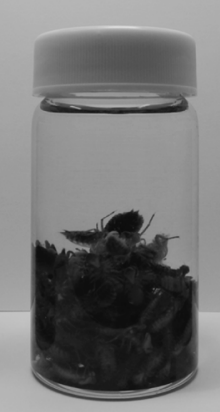

(b)

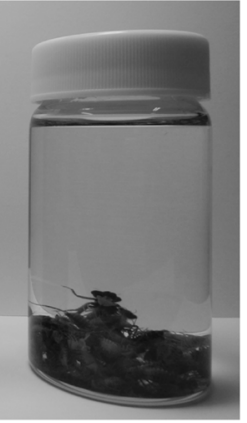

(c)
Fig. 5. Example of differences in number of individuals of dragonfly nymphs among (a) controls, (b) imidacloprid-, and (c) fipronil-treated fields.

着性の高いフィプロニルによる曝露を受けやすいと推察され る。また，世代期間の長さも，曝露後影響や回復性を評価す るうえでは重要な生態的特性であると言える.

これまでのリスク評価は主に，プランクトン，バクテリ アや藻類等，世代期間の短い生物種を対象に行われてき た ${ }^{30-32)}$. 生活史サイクルの長い生物種を考慮しないリスク 評価は, 農薬の安全性を過小に評価してしまう可能性が高い と考えられる ${ }^{16)}$ ， その意味においても，生物多様性に対す る農薬の真のリスクを評価するうえでは，2年以上のモ二タ リングを実施することが望ましい。
試験開始時に放流したヒメダカについて, 農薬曝露によ る奇形, 遊泳阻害 ${ }^{33)}$ や死亡個体が見られなかった理由とし て，両剂の魚類に対する急性影響濃度はそれぞれ 105,000 $211,000 \mu \mathrm{g} / \mathrm{L}$ (イミダクロプリド), $85 \sim 340 \mu \mathrm{g} / \mathrm{L}$ （フィプロ 二ル）であり ${ }^{17)}$, 水田メソコスム内の濃度はこれら急性影 響濃度を大きく下回っているためと考える. しかし, 魚類の 健全性の指標の一つである体サイズ比 ${ }^{16,19,34)}$ については, 処 理区間で比較を行った結果, 無処理区と農薬処理区との間で 有意な差が見られた。特に, この傾向はイミダクロプリド処 理区で顕著に見られた。さらに，体サイズへの影響は，試験 開始時に放流された個体に留まらず，次世代の個体にいたる まで, 慢性的に影響していた。これは，水中に拡散しやすい イミダクロプリド剤の曝露に伴う慨資源としての動物プラン クトンの減少，という間接効果によるもの，もしくは，農薬 曝露に対する解毒, 代謝に, 本来, 成長に用いるべきエネル ギーコストの一部を転換したことによるものと想定される.

これら実験生態系 (メソコスム) 試験から得られる情報 は, 生物学的複雑さ, すなわち生物多様性そのものであるこ とから, 生物多様性への影響を総合的に評価する手法の一つ として極めて有効であることは疑いないものである. 一方, 生態系影響評価には多大な労力とコストがかかるのも事実で あることから, 実用化に向けてはある程度限られたものにな らざるを得ず，また，データ不足や不確実性に対応可能なり スク解析手法の開発が必要である ${ }^{35)}$. さらに, 環境の不確 
実性や生物間相互作用等が複雑に絡み合うことで検出・予測 が難しい低濃度曝露 ${ }^{36)}$ に対する評価手法の開発も望まれる.

\section{4. 農薬の物理化学的性状の違いが示すこと}

本研究を通じて, 物理化学的性状の異なる農薬が, 水田に おける生物多様性に及ぼす影響の違いを明らかにすることが できた，水溶性が高く，土壌吸着性の低いイミダクロプリド は，水中浮遊・生活者に対して高い生態影響を及ぼしたが, 分解性も早いことから影響は一時的であった。しかし, 餌資 源としての動物プランクトンの減少に伴う魚類の成長阻害と いう間接影響を引き起こした可能性が示唆された。一方, 疎 水性で土壤吸着性の高いフィプロニルは，主に土袞生活者に 対して強い負の影響を与え，また，長期残留による慢性影響 も見られたが，水中に溶け出す量は微量のため，水中浮遊・ 生活者に対する影響は相対的に小さいなど，異なる生態影響 のカスケード効果を示した。これは，両農薬の物理化学的性 状，すなわち水溶解性，土袞吸着性や試験生物に対する安全 性の違いが，曝露影響の差に結びついた結果と考えられ，実 際の野外環境における生態影響を議論するうえでは，化学物 質の物理化学的性状の違いによる環境中動態の違いも十分に 考慮する必要があることを示したものである ${ }^{8)}$. 同様の傾向 は, Sánchez-Bayo and Goka ${ }^{34)}$ において,「ドミノ倒し効果」 として報告されている.

\section{おわりに}

水田メソコスムを利用した一連の研究により，農薬施用に よる生態影響を議論するうえで，（1）農薬の物理化学的性状 の違いによる環境中動態と生物の生息域，（2）水生生物各 種の生活史サイクルを考慮した試験期間の設定，および（3） 食物連鎖を介した間接影響，の重要性を示すことができた。

本研究では水田内（On-farm）における農薬の影響を調心゙ たが，周辺生態系（Off-farm）における農薬のリスクを把握 するための基礎的知見を提供できたと考える。一方，前述の 通り生態系は極めて複雑なため，今回対象としたOn-farm の生物種が必ずしも, Off-farmの生物種と一致するとは限 らず，また，環境も大きく異なる．農薬の真のリスクを評価 するためには，それぞれの環境・生態系にフィットした試験 方法を個別に整備・開発する必要があると考える. 加えて, 畑地，果樹園等の陸域農生態系も含めた農薬の生態りスク評 価をより高度化し，生物多様性保全に繋げるための手法の確 立も進める必要がある.

本研究は国立環境研究所において, 国内外の多くの方々 との共同研究によって行われた。本研究を遂行するに当た り, 国立環境研究所五箇公一主席研究員には終始厚くご指 導，ご鞭撻を頂くとともに，同主席研究員室のスタッフ一同 には，データ取得から同定に至るまで多大なるご協力を賜っ た。ここに深く感謝の意を表す. Francisco Sánchez-Bayo博
士（The University of Sydney）にはメソコスム研究の試験計 画に当たり惜しみないご協力を頂いた．農業環境技術研究所 輿語靖洋研究コーディネータ, 永井孝志主任研究員, 横山淳 史主任研究員, 国立環境研究所林 岳彦主任研究員, および 土木研究所真野浩行研究員にはデー夕解析等において多大な ご助言を頂いた。また，本研究の取りまとめに際し，種々の 励ましとご協力を頂いた，日本植物防疫協会上路雅子技術顧 問，農業環境技術研究所桐谷圭治名誉研究員，岡山大学中筋 房夫名誉教授, 日本植物調節剂研究協会竹下孝史専務理事, 愛媛大学日鷹一雅准教授, 東京農工大学渡邊裕純教授, 本林 隆講師, 宮城大学神宮字 寬准教授, および石川県立大学上 田哲行教授に心から感謝の意を表す。なお，本研究の一部 は，環境省事業「農薬による生物多様性への影響調査」の補 助を受けて行われた。

付 記

本稿のうち主張や考察に関する部分は著者の個人的見解で あり，所属組織，や環境省としての見解ではない。

\section{引用 文 献}

1) M. J. Swift and J. M. Anderson: "Biodiversity and Ecosystem Function," ed. by E. D. Schulze and H. A. Mooney, Springer, Berlin, pp. 15-41, 1994.

2) OECD: "Guidelines for Ecotoxicologic Testing of Chemicals," OECD, Paris, 1982.

3）横山淳史：農薬誌 36, 434-439 (2011).

4）五箇公一，早坂大亮：環境毒性誌 16, 21-28 (2013).

5) Y. Wu, C. Lin and L. Yuan: Ecol. Indic. 7, 768-775 (2007).

6) D. Hayasaka, T. Suzuki, T. Nomura, M. Nishiyama, T. Nagai, F. Sánchez-Bayo and K. Goka: J. Pestic. Sci. 38, 44-47 (2013).

7) R. A. Pastorok, S. M. Bartell, S. Ferson and L. R. Ginzburg (eds.): "Ecological Modeling in Risk Assessment: Chemical Effects on Population, Ecosystem and Landscapes," Lewis, Boca Raton, 2001.

8）早坂大亮, 永井孝志, 五箇公一：生態誌 63, 193-206 (2013).

9) L. Posthuma, G. W. Suter and T. P. Traas (eds.): "Species Sensitivity Distributions in Ecotoxicology (Environmental and Ecological Risk Assessment)," Lewis Publishers, CRC Press, 2002.

10) T. Nagai and A. Yokoyama: J. Pestic. Sci. 37, 233-239 (2012).

11) P. J. Campbell, D. J. S. Arnold, T. C. M. Brock, N. J. Grandy, W. Heger, F. Heimbash, S. J. Maund and M. Streloke (eds.): "Guideline Document, Higher-tier Aquatic Risk Assessment for Pesticides (HARAP)," SETAC-Europe Publication, Brussels, 1999.

12) 村岡哲郎：農薬環境科学 14, 7-22 (2006).

13）西條八束, 坂本 充: メソコスム湖沼生態系の解析, 名古屋大学 出版会, 愛知, 1993.

14) U. Riebesell, K. G. Schulz, R. G. J. Bellerby, M. Botros, P. Fritsche, M. Meyerhöfer, C. Neill, G. Nondal, A. Oschlies, J. Wohlers and E. Zöllner: Nature 450, 545-549 (2007).

15) M. Liess and M. Beketov: Ecotoxicology 20, 1328-1340 (2011). 
16) D. Hayasaka, T. Korenaga, K. Suzuki, F. Saito, F. Sánchez-Bayo and K. Goka: Ecotoxicol. Environ. Saf. 80, 355-362 (2012).

17）日本植物防疫協会：農薬ハンドブック 2011 年版, 日本植物防疫 協会, 東京, 2011.

18) D. Hayasaka, T. Korenaga, K. Suzuki, F. Sánchez-Bayo and K. Goka: Ecotoxicology 21, 421-427 (2012).

19) D. Hayasaka, T. Korenaga, F. Sánchez-Bayo and K. Goka: Ecotoxicology 21, 191-201 (2012).

20) D. Q. Thuyet, B. C. Jorgenson, C. Wissel-Tyson, H. Watanabe and T. M. Young: Sci. Total Environ. 414, 515-524 (2012).

21) H. Watanabe and K. Takagi: Environ. Technol. 21, 1393-1404 (2000).

22) D. Q. Thuyet, H. Watanabe, K. Yamazaki and K. Takagi: Bull. Environ. Contam. Toxicol. 86, 548-553 (2011).

23) D. P. R. Californiaa: "Environmental fate of imidacloprid," (http:// www.cdpr.ca.gov/docs/emon/pubs/envfate.htm), 2006.

24) A. Colville, P. Jones, F. Pablo, F. Krassoi, G. Hose and R. Lim: Ecotoxicology 17, 173-180 (2008).

25) A. L. Downing, K. M. DeVanna, C. N. Rubeck-Schurtz, L. Tuhela and H. Grunkemeyer: Ecotoxicology 17, 539-548 (2008).

26) S. Knillmann, N. C. Stampfli, M. A. Beketov and M. Liess: Ecotoxicology 21, 1857-1866 (2012).

27) SANCO (Santé des Consommateurs): "Guideline document on aquatic ecotoxicology in the context of the Directive 91/414/ EEC," European Commission, Health \& Consumer Protection Directorate-General, SANCO/3268/2001 ver.4 (final), Brussels, 2002.

28) K. H. Reinert, J. M. Giddings and L. Judd: Environ. Toxicol. Chem. 21, 1977-1992 (2002).

29）早坂大亮, 鈴木一隆, 是永知子, 諸岡（斎藤）歩希, 野村拓 志, 深澤圭太, Sánchez-Bayo F, 五箇公一: 農薬誌 38, 101-107 (2013).

30) T. Hanazato and M. Yasuno: Arch. Environ. Contam. Toxicol. 19, 77-83 (1990).

31) M. E. DeLorenzo, J. Lauth, P. L. Pennington, G. I. Scott and P. E. Ross: Aquat. Toxicol. 46, 241-251 (1999).

32) S. Mohr, M. Feibicke, R. Berghahn, R. Schmiediche and R. Schmidt: Environ. Pollut. 152, 530-542 (2008).

33) K. Goka: Environ. Res. A 81, 81-83 (1999).

34) F. Sánchez-Bayo and K. Goka: Environ. Toxicol. Chem. 25, 16771687 (2006).

35) 林 岳彦, 岩崎雄一, 藤井芳一 : 生態誌 60, 327-336 (2010).

36) M. Liess, R. B. Schäfers and C. A. Schriever: Sci. Total Environ. 406, 484-490 (2008).

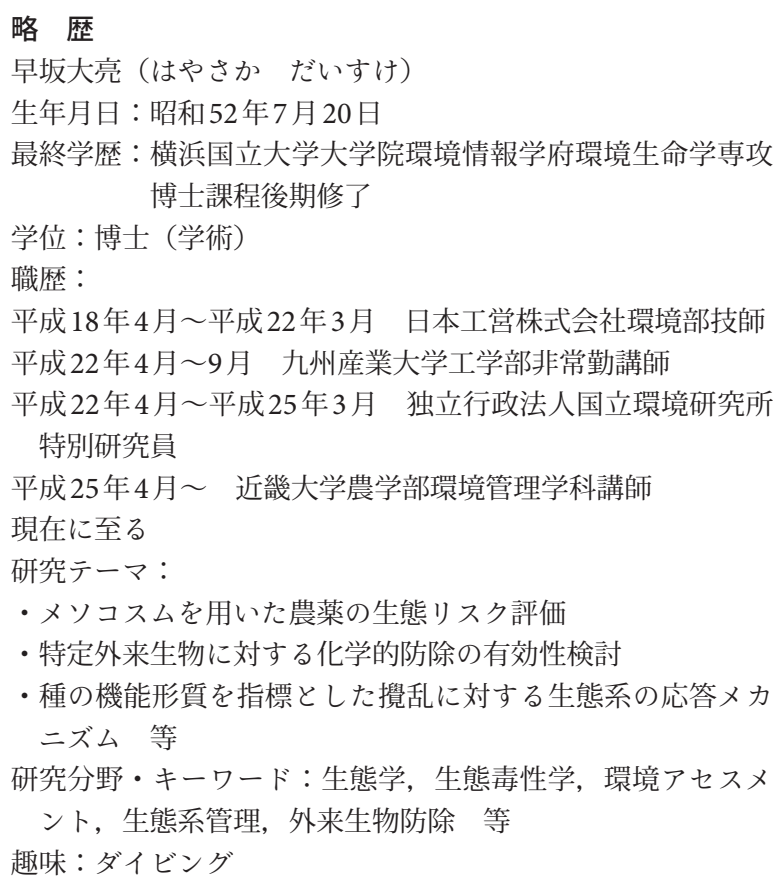

